\title{
Inability to conceive and treatment-seeking behaviour in Uttar Pradesh state in India
}

\author{
Brijesh P. Singh \\ Upasana Shukla ${ }^{1}$
}

\begin{abstract}
An attempt is made to estimate the prevalence of inability to conceive (commonly referred to as infertility) and treatment-seeking behaviour in the Indian state of Uttar Pradesh, using the District Level Household Survey data collected in 2007-08 (DLHS-3). In Uttar Pradesh, infertility is estimated to be about 11 per cent in females aged 20-34 among the total ever-married women of reproductive age (20-49) whose marital duration is more than two years. Among infertile respondents, more than three-quarters suffer from primary infertility. Also, about 85.0 per cent of women seek treatment for lifetime infertility.
\end{abstract}

Keywords: infertility, lifetime infertility, current primary infertility, childlessness.

\section{Résumé}

Dans cet article, une tentative a été faite pour estimer la prévalence de l'incapacité de concevoir (qui est communément appelé l'infertilité) et de son traitement le comportement de recherche dans l'Uttar Pradesh, État de l'Inde en utilisant les enquêtes auprès des ménages de niveau de district (DLHS-3) données recueillies en 2007 -08. Dans l'Uttar Pradesh l'infertilité est estimée à environ 11 pour cent de femmes âgées de 20--34 du total jamais des femmes mariées en âge de procréer 20-49, dont la durée du mariage est plus de deux ans. Parmi les répondants infertiles plus de trois-quarts souffrait d'infertilité primaire. Aussi pourcentage de femmes qui cherchent un traitement pour l'infertilité vie est d'environ 85,0 pour cent.

Mots-clés : l'infertilité, l’infertilité vie, infertilité primaire actuelle, infécondité.

\section{Introduction}

Infertility is essentially defined as the inability to conceive a baby. Infertility has been relatively neglected in South Asia, as both a health problem and a subject for social science research. The general thrust of programs and research has been on the correlates of high fertility and its regulation rather than on understanding the context of infertility, its causes and consequences (Jejeebhoy 1998). Infertility also has severe consequences for the well-being of men and, particularly, women. Despite this, there is even less social science research on the consequences of infertility than on its determinants. Though the ICPD Programme of Action states that reproductive health services should include the prevention and appropriate treatment of infertility (United Nations 1994), there is an inadequate focus on infertility in India's reproductive health program.

1. Dr. Brijesh P. Singh, Asst. Professor (Statistics), Faculty of Commerce \& DST-CIMS, Banaras Hindu University, Varanasi, India. Corresponding author: Upasana Shukla, JRF, Department of Statistics \& DSTCIMS, Banaras Hindu University, Varanasi, Uttar Pradesh, India. Email: shuklaupasana2005@gmail.com. 
Childlessness and infertility are rising dramatically in cities. Possible reasons for this may include sexually transmitted infections, coping with stress, lifestyle, job pressure, postponing parenthood, galloping urbanization, obesity, etc. Based on the census reports of India for 2001, 1991, and 1981, researchers show that childlessness in India has increased by 50 per cent since 1981. The marital childlessness rate (number of ever-married women aged 15-44 with no children ever, compared to the total population of ever-married women in the same age group) has gone up from 11 to 16 per cent, and permanent childlessness has zoomed from 3.89 to 7.47 per cent (Tripathi 2011).

In the past, a few studies were done in India to estimate infertility, but they were confined to particular cities or districts. Special questionnaires were prepared for them, and only infertile couples were part of these surveys. Such a study was done in Mysore (a city in Karnataka state) to investigate the relationship between bacterial vaginitis and acquisition of the herpes simplex virus type- 2 infection (HSV-2; Adamson et al. 2011). In this study, the specific causes of infertility were recorded and later analyzed.

Uttar Pradesh is the most populous state of India, as well as highly fertile one, but reliable estimates of infertility and demand for medical care have not been available to date. We were interested in studying the circumstances surrounding infertility in a highly fertile state. Therefore, in this study we attempt to estimate childlessness in Uttar Pradesh indirectly, from information on women's birth history, and infertility from some direct questions on infertility and health-seeking behaviour among currently married females.

The objectives of the present study of women in Uttar Pradesh are:

1. to estimate the prevalence of infertility and childlessness and treatment-seeking behaviour for infertility using selected socioeconomic and demographic characteristics;

2. to determine and compare the estimates of lifetime infertility, current infertility, and childlessness; and

3. to calculate the risk of treatment-seeking behaviour, based on selected socioeconomic and demographic characteristics.

\section{Background and literature review}

Marriage is nearly universal in India, with the median age at marriage being 17.2 years for females and 23.4 years for males in the age group 20-49 years (NFHS-3 2007). The desire to have children is powerful and widespread. In a patriarchal setting such as India, bearing children-particularly sons-largely defines a woman's identity (Widge and Cleland 2009). Motherhood is of great social significance, and infertility is perceived as a threat to men's procreativity and continuity of the lineage (Jindal and Gupta 1989; Singh and Dhaliwal 1993; Patel 1994; Iyengar and Iyengar 1999; Unisa 1999; Mulgaonkar 2001). Women who fail to produce a live birth are often denigrated and are considered to be luckless. Childless men and women are stigmatized and are likely to be discriminated against (Unisa 1999; Dyer et al. 2002; Ombelet et al. 2008). One partner may seek to blame the other as being incapable or unwilling. Childless couples are also excluded from taking leading roles in important family functions and events, such as birthdays, christenings, confirmations, bar mitzvahs, and weddings (Unisa 1999). Socially, most societies are organized, especially in the developing countries, such that children are utilized for the care and maintenance of older parents. Even in developed countries with social support systems, children and family are expected to provide a lot of care for the elderly (Rutstein and Shah 2004). Often the ill effects of childlessness are far more severe for women than they are for men. The "blame" for infertility is unquestioningly placed on the woman (Jejeebhoy 1998). Relationships between couples can become very strained 
Singh and Shukla: Inability to conceive and treatment-seeking behaviour in Uttar Pradesh state in India

when they do not bear children, and sometimes this leads to violence and even marital disruption (Widge and Cleland 2009; Dyer et al. 2002; Ombelet et al. 2008). Childless males could be compelled into a second marriage, which results in the life of the first wife becoming even worse. Also, some females are forced to secretly liaise with multiple sex partners, so that they can conceive and the marriage couple can dispel social discrimination. Though childlessness usually has a negative impact on the marriage, some husbands are supportive and do defend their wives against family pressure or criticism (Widge and Cleland 2009).

Infertility can be either voluntary or involuntary. Research has shown that voluntary childlessness is negligible in India (Unisa 2010). Around 95 per cent of couples desire to have children at some point in their lives. Therefore, even in the urban Indian context, childlessness is not due to women opting to remain single or childless by choice (Tripathi 2011), so infertile people can be described as involuntarily childless. Among them, some do subsequently conceive naturally, while others are not able. About 7 per cent of females remain childless because of either male or female infertility or both, while 16-20 per cent of couples are affected by infertility at some point in their lives (Shaw 2013).

According to the World Health Organisation (WHO), more than 180 million couples have to deal with childlessness, and this figure is increasing day by day. Many studies have been conducted in Africa, where the reported prevalence of infertility ranges from 9 per cent in Gambia to 30 per cent in Nigeria. In developing countries, the most important causes of childlessness are severe male infertility due to sexually transmitted diseases and female infertility due to blockage of tubes (Ombelet and Balen 2012). Both these problems can be treated by expensive assisted reproductive technologies (ART), which are not easily available everywhere-and, if available, they are mostly in the private sector and are costly (Ombelet and Balen 2012).

Age is a critical factor in infertility, and is a particularly relevant factor for women. Peak reproductive age is between 19 and 25 years, and fertility drops significantly after the mid-30s. In the current century, most women start reproduction when their fertility is already declining, i.e., late $20 \mathrm{~s}$ and early 30s. This is because of social factors and lifestyle choices, such as women entering the marriage market late and staying in the workforce, as well as using contraceptive methods due to the demands of their profession. Many women who wish to start reproduction in their mid- to late 30s are likely to have more difficulty in conceiving than younger women, and some will remain childless or only be able to have children through assisted reproduction, adoption, or foster care (Shaw 2013).

Infertility has multiple causes and consequences, depending on the gender, sexual history, lifestyle, society, and cultural background of the people it affects. Infertility may be due to problems in the female, male, or both. Among the major reasons for infertility are cancers or tumours, obesity, alcoholism, smoking, older age, diabetes, excessive exercising, pelvic infection, reproductive tract infections/sexually transmitted diseases, retrograde ejaculation, impotence, etc. Gender is not a significant factor in infertility: about 30 per cent of infertility cases are caused by female factors alone and 30 per cent by male factors alone; another 30 per cent are caused by combined female and male factors, and 10 per cent of infertility cases cannot be explained (Shaw 2013).

There are several types of treatment available for infertility, depending upon the nature of the infertility problem. Infertility treatment can be either traditional or biomedical. Important techniques include fertility drugs, artificial insemination (also known as Intrauterine Insemination or IUI), donor sperm, In Vitro Fertilization (IVF), Intracytoplasmic Sperm Injection (ICSI), donor eggs, surrogacy, donor embryos, reproductive surgery, and Zygote Intrafallopian Transfer (ZIFT). Also, most infertility clinics/centres are situated in cities. Therefore, persons residing in rural areas have to travel long distances for treatment, which ultimately increases the cost of the treatment. 
Infertility estimates (primary and secondary infertility) calculated at the end of the reproductive span of females have been found to be 8 per cent in India, 10 per cent in Pakistan, 11 per cent in Sri Lanka, 12 per cent in Nepal, and 15 per cent in Bangladesh (Jejeebhoy 1998). The WHO estimates the overall prevalence of primary infertility in India to be between 3.9 and 16.8 per cent. Estimates of infertility vary widely among the Indian states, from 3.7 per cent in Uttar Pradesh, Himachal Pradesh, and Maharashtra (Talwar, Go, and Murali 1986) to 5 per cent in Andhra Pradesh (Ram 2006) and 15 per cent in Kashmir (Zargar et al. 1997). Moreover, the prevalence of primary infertility has been shown to vary across tribes and castes within the same region in India (Talwar, Go, and Murali 1986).

\section{Data and methodology}

The Government of India initiated the District-Level Household Survey in 1997 with a view to assessing the utilization of district-level reproductive and child health services provided by government healthcare facilities, and people's perceptions about the quality of these services. Preceded by the DLHS-1 in 1998-99 and DLHS-2 in 2002-04, the third in the series of district surveys (DLHS3) was one of the largest-ever demographic and health surveys carried out in India, with a sample size of about 700,000 households covering all districts of the country. This survey was designed to provide estimates on important indicators of maternal and child health, family planning, and other reproductive health services. The DLHS-3 adopted a multi-stage stratified sampling design, with probability proportional to size.

Questionnaires were prepared in local languages as well as English. Separate questionnaires for village and health facilities were used to gather required information, whereas the household questionnaire collected information on all members of the household, as well as socioeconomic characteristics of the household, assets possessed, and number of marriages and deaths since January 2004. The ever-married women's questionnaire solicited information on women's characteristics, maternal care, immunization and childcare, contraception and fertility preferences, and reproductive health, including knowledge about reproductive tract infections (RTIs), sexually transmitted infections (STIs), and HIV/AIDS.

The present study is based on data extracted from the DLHS-3 that was conducted in Uttar Pradesh during 2007-08 for currently married females aged 20-34 years, whose exposure period to the risk of conception was at least two years. Taking part in the survey were 44,415 currently married females aged 20-34; among them, 4,763 females reported problems getting pregnant, and of these, 4,062 females obtained some sort of advice/treatment.

Infertility refers to an inability to conceive after having regular unprotected sex. The WHO defines infertility as failure to conceive despite two years of cohabitation and exposure to pregnancy. Infertility is of two types, primary and secondary. Using a two-year reference period, the WHO defines primary infertility as a lack of conception despite cohabitation and exposure to pregnancy (WHO 1991). Secondary infertility is defined as a failure to conceive following a previous pregnancy, despite cohabitation and exposure to pregnancy in the absence of contraception, breastfeeding, or postpartum amenorrhoea (WHO 1991). In this paper, the following terms are used:

Lifetime infertility: if a woman has ever had a problem getting pregnant (i.e., either primary and/ or secondary infertility);

Lifetime primary infertility: if a woman has ever had a problem conceiving for the first time (i.e., in reproductive life has ever had a problem of primary infertility); 
Singh and Shukla: Inability to conceive and treatment-seeking behaviour in Uttar Pradesh state in India

Current primary infertility: if a woman never had a live birth up to the interview date, and reported problems conceiving for the first time; and

Childlessness: if a woman never had a live birth up to the date of interview.

The study by Unisa (2010) gives infertility estimates for India as a whole; however, these estimates are not made at the state level in India. Moreover, it is well known that there is much variation in fertility from one state to another. Minimum total fertility rate (TFR) is found in Andhra Pradesh and Goa states, with a TFR of 1.79, followed by Tamil Nadu state with a TFR of 1.80 and Kerala state with a TFR of 1.93; maximum TFR (4.00) was found in Bihar state (NFHS-3 2007: 131-132). Uttar Pradesh is the most populous state of India, and its fertility is still high, with a TFR of 3.82 (NFHS-3 2007: 83), which is higher than the national fertility level of TFR 2.68 (NFHS-3 2007: 131). In this paper, we endeavour to estimate the prevalence of infertility in this high-fertility state.

Measurement of infertility is not an easy task, and in the absence of data on infertility in Uttar Pradesh, information on childlessness allowed us to infer some ideas about infertility. Then, for the first time, a new module regarding infertility and its treatment-seeking behaviour was added to the DLHS questionnaire, with respondents asked about their infertility problems and causes of the problems. There were seven questions in this module. The first question-whether the woman ever had a problem getting pregnant - was used to compute lifetime infertility (i.e., primary and secondary infertility both). The second question focused on the timing of the infertility problem. If the infertility problem (as identified in question one) occurred before the first birth, then it was considered primary infertility, but if the problem occurred after a live or still birth—or after an induced or spontaneous abortion, pelvic surgery, or some other incident/health problem) — then all such cases were considered secondary infertility. If a woman never had a live birth till the date of the interview (and she was not pregnant currently), then she was considered childless.

The survey included the full birth history information of the respondents. We computed current primary infertility on the basis of birth history information that specified no live birth up to the date of the interview, along with the first two questions of the infertility module about problems getting pregnant for the first time. While calculating current primary infertility, we removed the data on females of the same age and marital duration who were currently pregnant or using contraceptives.

Then we used the next survey question-whether the woman or her husband ever sought any advice/treatment - to calculate treatment-seeking behaviour. The subsequent question asked what type of treatment (Government allopathic care, private allopathic care, AYUSH, herbalist, traditional healer, religious / faith healing) was taken by the respondent or her husband. We divided these treatments into two categories, allopathic and others, where allopathic was further divided into government and private sector, and others encompassed all the other types of treatment besides allopathic.

The explanatory variables (socioeconomic and demographic) used in the study were: caste, religion, place of residence, current age of respondent, woman's education, husband's education, age at consummation of marriage, wealth index quintiles, marital duration, and zones of the state. Uttar Pradesh was divided into four zones: Bundelkhand, Eastern, Western, and Central. This paper elucidates the effect of the socioeconomic determinants on infertility. With the help of the survey data, we would like to see whether an infertility problem is prevalent in any group or specific area, and what opinions people have of the treatment. Binary Logistic regression and chisquare techniques were used, along with bivariate frequency distribution. The data were analysed using SPSS 16.0 software. 


\section{Results}

Table 1 presents the estimates of lifetime infertility (either primary or secondary), lifetime primary infertility, current primary infertility, and childlessness by socioeconomic characteristics. In

Table 1: Per cent distribution of infertility and childlessness according to some background characteristics among currently married females aged 20-34 years in Uttar Pradesh.

\begin{tabular}{|c|c|c|c|c|c|c|c|c|}
\hline \multirow[b]{3}{*}{$\begin{array}{l}\text { Background } \\
\text { characteristics }\end{array}$} & \multirow{3}{*}{$\begin{array}{c}\text { Lifetime } \\
\text { infertility } \\
(\mathrm{N}=44,415)\end{array}$} & \multirow[b]{3}{*}{$\begin{array}{c}\text { p-value } \\
\text { of } \chi^{2}\end{array}$} & \multirow{3}{*}{$\begin{array}{c}\text { Lifetime } \\
\text { primary } \\
\text { infertility } \\
(\mathrm{N}=44,415)\end{array}$} & \multirow[b]{3}{*}{$\begin{array}{c}\text { p-value } \\
\text { of } \chi^{2}\end{array}$} & \multicolumn{4}{|c|}{ Based on } \\
\hline & & & & & \multicolumn{2}{|c|}{$\begin{array}{l}\text { all women } \\
(\mathrm{N}=44,415)\end{array}$} & \multicolumn{2}{|c|}{$\begin{array}{c}\text { non-users of } \\
\text { contraceptives } \\
(\mathrm{N}=21,583)\end{array}$} \\
\hline & & & & & Childless & $\begin{array}{l}\text { Current } \\
\text { primary } \\
\text { infertility }\end{array}$ & Childless & $\begin{array}{l}\text { Current } \\
\text { primary } \\
\text { infertility }\end{array}$ \\
\hline \multicolumn{9}{|l|}{ Type of locality } \\
\hline Rural & 10.8 & \multirow{2}{*}{0.365} & 8.6 & \multirow{2}{*}{0.026} & 6.1 & 2.6 & 4.5 & 2.3 \\
\hline Urban & 10.4 & & 7.8 & & 5.3 & 2.5 & 3.7 & 2.4 \\
\hline \multicolumn{9}{|l|}{ Current age (years) } \\
\hline $20-24$ & 10.9 & \multirow{3}{*}{0.694} & 8.9 & \multirow{3}{*}{0.052} & 12.8 & 4.4 & 9.0 & 3.8 \\
\hline $25-29$ & 10.8 & & 8.3 & & 4.2 & 2.3 & 3.1 & 2.1 \\
\hline $30-34$ & 10.6 & & 8.1 & & 2.0 & 1.4 & 1.7 & 1.3 \\
\hline \multicolumn{9}{|l|}{ Religion } \\
\hline Hindu \& others & 10.9 & \multirow{2}{*}{0.031} & 8.6 & \multirow{2}{*}{0.003} & 6.2 & 2.6 & 4.5 & 2.4 \\
\hline Muslim & 10.0 & & 7.6 & & 4.9 & 2.5 & 3.6 & 2.2 \\
\hline \multicolumn{9}{|l|}{ Caste* $^{*}$} \\
\hline $\mathrm{SC} / \mathrm{ST}$ & 10.0 & \multirow{3}{*}{0.049} & 7.9 & \multirow{3}{*}{0.033} & 6.3 & 2.7 & 4.6 & 2.4 \\
\hline $\mathrm{OBC}$ & 11.0 & & 8.7 & & 6.1 & 2.6 & 4.5 & 2.3 \\
\hline Others & 10.8 & & 8.3 & & 5.2 & 2.5 & 3.8 & 2.3 \\
\hline \multicolumn{9}{|l|}{ Woman's education (years) } \\
\hline No schooling & 10.8 & & 8.6 & & 5.3 & 2.6 & 4.0 & 2.3 \\
\hline Primary & 12.1 & & 9.5 & & 6.5 & 3.0 & 4.6 & 2.8 \\
\hline High school & 11.6 & 0.000 & 9.2 & 0.000 & 7.0 & 2.8 & 5.1 & 2.4 \\
\hline Higher education & 8.7 & & 6.5 & & 8.2 & 2.6 & 5.3 & 2.3 \\
\hline Husband's education (ye & rs) & & & & & & & \\
\hline No schooling & 10.5 & & 8.1 & & 5.3 & 2.6 & 3.8 & 2.3 \\
\hline Primary & 11.6 & & 8.8 & & 4.6 & 2.0 & 3.5 & 1.9 \\
\hline High school & 11.1 & $0.1 / 1$ & 8.9 & $0.0 / 2$ & 6.0 & 2.8 & 4.6 & 2.5 \\
\hline Higher education & 10.4 & & 8.2 & & 6.6 & 2.6 & 4.5 & 2.2 \\
\hline Age at consummation of & marriage & & & & & & & \\
\hline Below 18 years & 11.2 & & 8.9 & & 4.3 & 2.3 & 3.2 & 2.1 \\
\hline $18+$ years & 10.1 & 0.000 & 7.8 & 0.000 & 8.4 & 3.0 & 5.6 & 2.7 \\
\hline Wealth Index Quintiles & & & & & & & & \\
\hline Poorest & 10.1 & & 7.8 & & 5.3 & 2.4 & 4.1 & 2.2 \\
\hline Second & 10.8 & & 8.6 & & 6.1 & 2.7 & 4.3 & 2.4 \\
\hline Middle & 10.6 & 0.020 & 8.6 & 0.002 & 6.4 & 2.8 & 4.7 & 2.5 \\
\hline Fourth & 11.6 & & 9.3 & & 6.6 & 2.7 & 4.7 & 2.4 \\
\hline Richest & 10.6 & & 7.8 & & 5.5 & 2.4 & 3.8 & 2.1 \\
\hline Geographic zones & & & & & & & & \\
\hline Bundelkhand & 7.0 & & 5.5 & & 5.5 & 2.3 & 3.8 & 2.1 \\
\hline Central & 12.7 & & 10.0 & & 3.8 & 2.2 & 3.0 & 2,0 \\
\hline Western & 11.1 & 0.000 & 8.8 & 0.000 & 5.4 & 2.9 & 3.9 & 2.6 \\
\hline Eastern & 9.7 & & 7.6 & & 8.2 & 2.8 & 5.9 & 2.5 \\
\hline Marital duration (years) & & & & & & & & \\
\hline $02-05$ & 9.7 & & 8.1 & & 19.4 & 5.3 & 13.1 & 4.5 \\
\hline $05-10$ & 10.9 & & 8.7 & & 8.3 & 3.6 & 5.9 & 3.2 \\
\hline $10-15$ & 11.0 & 0.076 & 8.5 & 0.434 & 3.4 & 2.0 & 2.6 & 1.8 \\
\hline $15+$ & 10.5 & & 8.2 & & 2.1 & 1.5 & 1.8 & 1.4 \\
\hline Uttar Pradesh state level & 10.7 & & 8.4 & & 6.0 & 2.6 & 4.3 & 2.3 \\
\hline
\end{tabular}

* SC-Scheduled Caste; ST-Scheduled Tribe; OBC-Other Backward Class. 
Singh and Shukla: Inability to conceive and treatment-seeking behaviour in Uttar Pradesh state in India

Uttar Pradesh, 10.7 per cent of women aged 20-34 whose marital duration was more than two years suffer from lifetime infertility, and among them, three-quarters suffer from lifetime primary infertility. The percentage of childless women is 6.0 per cent, while 3.0 per cent of women have current primary infertility. In contrast, the estimates of childlessness and current primary infertility are found to be 4.0 per cent and 2.3 per cent, respectively, which show that childlessness is negligible in India, i.e., people are childless by chance and not by their choice (Tripathi 2011). The childlessness rate is highest in the age group 20-24 years, and then declines rapidly until age 30-34, and stabilizes thereafter. This is true for both rural and urban areas throughout the time period under analysis. Infertility and childlessness estimates are higher among the Hindu and other religions than Muslims. Also, a higher proportion of women suffers in rural areas than urban, because of a lack of health facility centres as well as illiteracy. The illiterate and less-educated women usually go for infertility treatment to temples, religious or traditional healers, astrologers, and charlatans, observing tantric rites, wearing charms, and participating in fertility rituals (Patel 1994; Unisa 1999). A large proportion of rural couples is totally dependent on government health facilities for treatment, but adequate services are not provided there. It is also observed that infertility and childlessness estimates are higher among those whose age at marriage is below 18 years. On the other hand, education of the woman and her husband, wealth index quintiles, and caste of the woman show no relation to infertility or childlessness.

Regional disparity is found in the estimates of infertility and childlessness. In Uttar Pradesh, infertility estimates are highest in the Central zone, followed by Western, Eastern, and Bundelkhand, while childlessness is highest in the Eastern zone, followed by Western, Bundelkhand, and Central. The levels of lifetime infertility are almost constant among all the age groups, and show a slight decrease as age increases, while the levels of childlessness are highest among women aged 20-24 years, followed by 25-29 years. We used the chi-square test to measure the independence of socioeconomic factors on infertility, and the respective p-values are shown in the Table 1. Thus, we see that in Uttar Pradesh, infertility is not very much affected by sociodemographic characteristics, and therefore, there may be a possibility of some biological factors associated with infertility. However, since in the survey specific causes of infertility (like lower sperm count, fallopian tube blockage, RTIs/STDs, pelvic infections, etc.) were not queried, we cannot confidently say that higher estimates of infertility are because of some biological problems. The WHO report shows that the major cause of infertility in Asia was on account of either STIs or unsafe management of abortion or delivery.

Table 2 shows the advice- or treatment-seeking behaviour of couples who had ever had any infertility problem. In Uttar Pradesh, treatment seeking was highest among the urban, Muslims, and others caste groups, the richest, and central zone residents. Among these infertile couples having any infertility problem, 85 per cent took some advice or treatment; of these, the most (about 85 per cent) went for allopathic treatment. Among those who chose allopathic treatment, 24 per cent went to government health centres, while 68 per cent went to the private sector. "Poorest" and "second" Wealth Index Quintile people went to government hospitals, clinics, CHC/PHC/Subcentre, etc., while "richest" and "fourth" people went to private clinics. In the treatment-seeking category, multiple responses were obtained, so that the sum of total percentages exceeds 100 .

The mean age at effective marriage ${ }^{2}$ in Uttar Pradesh was found to be 16.8 years, which is lower than the legal minimum age of 18 years for females. Split out for rural and urban, these values were

2. In Uttar Pradesh there is a tradition of childhood as well as teen marriage preferred for girls. Typically, a few years after a girl has been married, when the girl is in her teens, she goes to live in her husband's house. This practice is called gauna, the age when a girl is effectively married. Therefore in this study we consider this age as the effective age at marriage. 
Table 2: Lifetime infertility treatment-seeking behaviour of currently married females aged 20-34 years in Uttar Pradesh according to some background characteristics.

\begin{tabular}{|c|c|c|c|c|c|c|}
\hline \multirow[b]{3}{*}{ Background characteristics } & \multirow{3}{*}{$\begin{array}{c}\text { Average } \\
\text { waiting time } \\
\text { to first birth } \\
\text { (in years) }\end{array}$} & \multicolumn{4}{|c|}{ Lifetime infertility treatment } & \multirow[b]{3}{*}{$\mathrm{N}$} \\
\hline & & \multirow{2}{*}{$\begin{array}{c}\text { Any type } \\
\text { of advice or } \\
\text { treatment }\end{array}$} & \multicolumn{2}{|c|}{ Allopathic treatment* } & \multirow{2}{*}{$\begin{array}{l}\text { Other } \\
\text { treatment* }\end{array}$} & \\
\hline & & & Government & Private & & \\
\hline \multicolumn{7}{|l|}{ Type of locality } \\
\hline Rural & 4.8 & 84.5 & 24.3 & 67.2 & 35.6 & 3,396 \\
\hline Urban & 4.2 & 89.6 & 22.9 & 71.4 & 41.5 & 666 \\
\hline \multicolumn{7}{|l|}{ Current age (years) } \\
\hline $20-24$ & 3.7 & 80.4 & 24.9 & 67.9 & 18.5 & 1,141 \\
\hline $25-29$ & 4.6 & 87.5 & 23.6 & 69.9 & 32.2 & 1,524 \\
\hline $30-34$ & 5.4 & 87.3 & 24.1 & 65.6 & 37.7 & 1,397 \\
\hline \multicolumn{7}{|l|}{ Religion } \\
\hline Hindu \& others & 4.8 & 84.5 & 24.4 & 67.4 & 36.3 & 3,413 \\
\hline Muslim & 4.1 & 90.0 & 22.3 & 70.3 & 36.5 & 649 \\
\hline \multicolumn{7}{|l|}{ Caste $^{* *}$} \\
\hline $\mathrm{SC} / \mathrm{ST}$ & 4.9 & 77.9 & 30.0 & 62.1 & 39.2 & 744 \\
\hline $\mathrm{OBC}$ & 4.7 & 86.2 & 22.5 & 67.4 & 36.4 & 2,399 \\
\hline Others & 4.5 & 89.7 & 23.5 & 73.8 & 32.5 & 919 \\
\hline \multicolumn{7}{|l|}{ Woman's education (years) } \\
\hline No schooling & 4.9 & 84.0 & 24.9 & 65.7 & 37.2 & 2,777 \\
\hline Primary & 4.6 & 87.3 & 21.2 & 61.1 & 38.6 & 193 \\
\hline High school & 4.3 & 87.8 & 22.6 & 72.0 & 32.1 & 649 \\
\hline Higher education & 3.8 & 89.7 & 22.7 & 78.4 & 24.4 & 443 \\
\hline \multicolumn{7}{|l|}{ Husband's education (years) } \\
\hline No schooling & 4.9 & 80.7 & 25.3 & 63.9 & 40.0 & 1,014 \\
\hline Primary & 4.3 & 83.9 & 23.7 & 63.8 & 42.9 & 177 \\
\hline High school & 4.9 & 86.2 & 22.3 & 67.2 & 37.1 & 1,499 \\
\hline Higher education & 4.4 & 88.2 & 25.2 & 72.1 & 29.5 & 1,372 \\
\hline \multicolumn{7}{|c|}{ Age at consummation of marriage } \\
\hline Below 18 years & 5.2 & 85.2 & 25.7 & 65.4 & 37.6 & 2,481 \\
\hline $18+$ years & 3.9 & 85.5 & 23.3 & 71.7 & 29.7 & 1,581 \\
\hline \multicolumn{7}{|l|}{ Wealth Index Quintiles } \\
\hline Poorest & 5.3 & 79.7 & 25.8 & 63.5 & 39.6 & 757 \\
\hline Second & 5.1 & 82.3 & 27.3 & 64.0 & 37.2 & 810 \\
\hline Middle & 4.6 & 85.2 & 22.4 & 65.3 & 41.7 & 807 \\
\hline Fourth & 4.5 & 88.3 & 24.2 & 68.7 & 29.3 & 906 \\
\hline Richest & 4.0 & 91.6 & 20.9 & 77.9 & 29.6 & 782 \\
\hline \multicolumn{7}{|l|}{ Geographic zones } \\
\hline Bundelkhand & 5.8 & 81.8 & 39.1 & 38.2 & 71.4 & 220 \\
\hline Central & 4.1 & 92.3 & 16.7 & 69.8 & 43.1 & 1,605 \\
\hline Western & 5.1 & 81.7 & 26.1 & 67.0 & 36.8 & 920 \\
\hline Eastern & 5.2 & 80.9 & 29.2 & 71.1 & 27.3 & 1,317 \\
\hline \multicolumn{7}{|l|}{ Marital duration (years) } \\
\hline $02-05$ & 2.2 & 78.2 & 21.2 & 69.9 & - & 316 \\
\hline $05-10$ & 3.7 & 84.2 & 23.8 & 71.0 & - & 1,210 \\
\hline $10-15$ & 4.8 & 87.3 & 24.1 & 67.7 & - & 1,354 \\
\hline $15+$ & 5.8 & 86.3 & 25.2 & 64.4 & 36.3 & 1,182 \\
\hline Uttar Pradesh state level & 4.7 & 85.3 & 24.1 & 67.9 & 36.3 & 4,062 \\
\hline \multicolumn{7}{|c|}{$\begin{array}{l}\text { * Multiple responses were possible for type of treatment seeking. } \\
\text { ** SC-Scheduled Caste; ST-Scheduled Tribe; OBC-Other Backward Class. }\end{array}$} \\
\hline
\end{tabular}


Table 3 represents the risk of treatment-seeking behaviour for different socioeconomic characteristics of the woman. We see that there are differences in the treatment-seeking behaviour of couples having any infertility problem by socioeconomic and demographic variables. The odds ratio of treatment seeking is higher in urban areas than rural areas. This may be primarily due to better availability and accessibility in urban areas. On the other hand, because all couples have a desire to have children, educational attainment is immaterial. Neither do age at consummation of marriage or zones of the state have any significant effect. Odds of treatment seeking are doubled in the age

Table 3: Results of odds ratio on treatment-seeking behaviour among infertile women.

\begin{tabular}{|c|c|c|c|c|}
\hline \multirow{2}{*}{ Background characteristics } & \multirow{2}{*}{$\operatorname{Exp}(B)$} & \multirow{2}{*}{ Significance } & \multicolumn{2}{|c|}{$95 \%$ confidence interval } \\
\hline & & & Upper limit & Lower limit \\
\hline \multicolumn{5}{|l|}{ Type of locality } \\
\hline \multicolumn{5}{|l|}{ Rural (ref) } \\
\hline Urban & 1.584 & 0.000 & 1.233 & 2.036 \\
\hline \multicolumn{5}{|l|}{ Current age (years) } \\
\hline \multicolumn{5}{|l|}{$20-24$ (ref) } \\
\hline $25-29$ & 1.703 & 0.000 & 1.404 & 2.066 \\
\hline $30-34$ & 1.677 & 0.000 & 1.377 & 2.042 \\
\hline \multicolumn{5}{|l|}{ Religion } \\
\hline \multicolumn{5}{|l|}{ Hindu \& others (ref) } \\
\hline Muslim & 1.656 & 0.000 & 0.898 & 1.070 \\
\hline \multicolumn{5}{|l|}{ Caste* } \\
\hline \multicolumn{5}{|l|}{$\mathrm{SC} / \mathrm{ST}$ (ref) } \\
\hline $\mathrm{OBC}$ & 1.776 & 0.000 & 1.473 & 2.142 \\
\hline Others & 2.482 & 0.000 & 1.927 & 3.198 \\
\hline \multicolumn{5}{|l|}{ Woman's education (years) } \\
\hline \multicolumn{5}{|l|}{ No schooling (ref) } \\
\hline Primary & 1.316 & 0.187 & 0.876 & 1.977 \\
\hline High school & 1.376 & 0.009 & 1.083 & 1.748 \\
\hline Higher education & 1.658 & 0.001 & 1.223 & 2.248 \\
\hline \multicolumn{5}{|l|}{ Husband's education (years) } \\
\hline \multicolumn{5}{|l|}{ No schooling (ref) } \\
\hline Primary & 1.242 & 0.279 & 0.839 & 1.840 \\
\hline High school & 1.491 & 0.000 & 1.226 & 1.813 \\
\hline Higher education & 1.789 & 0.000 & 1.453 & 2.204 \\
\hline \multicolumn{5}{|c|}{ Age at consummation of marriage } \\
\hline \multicolumn{5}{|c|}{$18+$ years $(\mathrm{ref})$} \\
\hline Below 18 years & 1.019 & 0.826 & 0.864 & 1.201 \\
\hline \multicolumn{5}{|l|}{ Wealth Index Quintiles } \\
\hline \multicolumn{5}{|l|}{ Poorest (ref) } \\
\hline Second & 1.187 & 0.140 & .945 & 1490 \\
\hline Middle & 1.470 & 0.002 & 1.157 & 1.867 \\
\hline Fourth & 1.925 & 0.000 & 1.503 & 2.465 \\
\hline Richest & 2.769 & 0.000 & 2.073 & 3.695 \\
\hline \multicolumn{5}{|l|}{ Geographic zones } \\
\hline \multicolumn{5}{|l|}{ Bundelkhand (ref) } \\
\hline Central & 2.688 & 2.688 & 1.882 & 3.839 \\
\hline Western & 0.995 & 0.995 & 0.705 & 1.404 \\
\hline Eastern & 0.943 & 0.943 & 0.676 & 1.316 \\
\hline \multicolumn{5}{|l|}{ Marital duration (years) } \\
\hline $02-05$ (ref) & & & & \\
\hline $05-10$ & 1.484 & 0.000 & 1.127 & 1.955 \\
\hline $10-15$ & 1.914 & 0.000 & 1.447 & 2.531 \\
\hline $15+$ & 1.760 & 0.000 & 1.328 & 2.334 \\
\hline
\end{tabular}

(ref) $=$ reference category

* SC-Scheduled Caste; ST-Scheduled Tribe; OBC-Other Backward Class. 
groups 25-29 and 30-34 years compared to 20-24, and a similar result is seen for marital duration, because couples wait a few years for children and start seeking treatment only after that.

Overall, a large number of couples in Uttar Pradesh that have any problems conceiving seek treatment. A higher number of women are now going for allopathic treatment. It is interesting that the percentage of women going for treatment in the private sector is more than double those going for treatment in the government sector. Treatment seeking is higher among Muslims than Hindus and other religions. The percentage of treatment seeking increases as the wealth index increases, and urban couples seek more treatment because health facilities are more easily available as compared to rural couples. Treatment-seeking percentage has a positive association with the education of the woman and her husband. Illiterate and primary-educated couples prefer treatment in the government sector, while those with high school and higher education prefer the private sector for treatment. Treatment seeking for lifetime infertility is highest in the Central zone, followed by Eastern, Bundelkhand and Western. Similar behaviour is observed for current primary infertility treatment. Though childlessness is highest among women aged 20-24 years, treatment seeking is highest in women aged 25-29 years. Among those couples who underwent infertility treatment, 71 per cent of the women conceived. As for the cause of problems with conception, 72 per cent reported it was only in the wife, while nearly 10 per cent of the women did not know the reason for their problems conceiving. Among females having infertility problems, 75 per cent reported infertility problems within 3 years after marriage.

\section{Conclusion and policy implication}

As Uttar Pradesh is a high-fertility state in India, infertility prevalence is also high in this state. Among females aged 20-34 of total ever-married women aged 20-49 in 2007-08, it was estimated at 11 per cent. This is higher than the figure for India as a whole, 8.8 per cent (Unisa 2010). Among those respondents who reported a problem of lifetime infertility in Uttar Pradesh, more than threequarters suffer from primary infertility. The estimates of childlessness and current primary infertility are 6.0 and 2.6 per cent, respectively. About 85.0 per cent of women seek treatment for lifetime primary and current primary infertility. However, given the treatment facilities available so far in the state, only 70 per cent of infertile women who took any treatment were able to conceive. So, there is a great need to improve medical facilities in the state, and especially in rural areas, because seeking treatment from religious or traditional healers and charlatans is more common there. For this, we have to spread much awareness about new treatment technologies available like ART, donor eggs, surrogacy, etc. Also, there is a need to improve infertility care services at government health centres, so that rural people do not have to travel to cities for infertility treatment.

\section{References}

Adamson, P.C., K. Krup, A.H. Freema, J.D. Klausnes, A. Reingold, and P. Madhivanan. 2011. Prevalence and correlates of primary infertility among young women in Mysore, India. The Indian Journal of Medical Research 134(4):440-446.

Dyer, S.J., and M. Patel. 2012. The economic impact of infertility on women in developing countries: A systematic review, in Biomedical Infertility Care in Poor Resource Countries: Barriers, Access, and Ethics, edited by T. Gerrits, W. Ombelet, F. van Balen, and S. Vanderpoel. Facts, Views and Vision in 
Singh and Shukla: Inability to conceive and treatment-seeking behaviour in Uttar Pradesh state in India

Obstetrics and Gynaecology: The Walking Egg Project. Wetteren (Belgium): Flemish Society of Human Reproduction and Embryology, p. 38-45.

Dyer, S.J., N. Abrahams, M. Hoffman, and Z.M. van der Spuy. 2002. Infertility in South Africa: Women's reproductive health knowledge and treatment-seeking behaviour for involuntary childlessness. Human Reproduction 17(6):1657-1662.

ICPD. 1994. Principle 8: Program of Action. Cairo: International Conference on Population and Development.

Iyengar, K., and S. Iyengar. 1999. Dealing with Infertility: Experience of a Reproductive Health Programme in Southern Rajasthan. National Consultation on Infertility Prevention and Management. New Delhi: UNFPA.

Jejeebhoy, S.J. 1998. Infertility in India: Levels, patterns and consequences: Priorities for social science research. Journal of Family Welfare 44(2):15-24.

Jindal, U.N., and A.N. Gupta. 1989. Social problems of infertile women in India. International Journal of Fertility 34:1-33.

Mulgaonkar, V.B. 2001. A Research and Intervention Programmes on Women's Reproductive Health in Slums of Mumbai. Sujeevan Trust.

NFHS-3. 2007. National Family Health Survey (NFHS-3), 2005-06: India. Mumbai: International Institute for Population Sciences and Macro International.

Ombelet, W., and F. van Balen. 2012. Future perspectives, in Biomedical Infertility Care in Poor Resource Countries: Barriers, Access, and Ethics, edited by T. Gerrits, W. Ombelet, F. van Balen, and S. Vanderpoel. Facts, Views and Vision in Obstetrics and Gynaecology: The Walking Egg Project. Wetteren (Belgium): Flemish Society of Human Reproduction and Embryology, p. 87-90.

Ombelet, W., I. Cooke, S. Dyer, G. Serour, and P. Devroey. 2008. Infertility and the provision of infertility medical services in developing countries. Human Reproduction Update 14(6):605-621.

Patel, T. 1994. Fertility Behaviour: Population and Society in a Rajasthan Village. Delhi: Oxford University Press.

Ram, U. 2006. Childlessness and Its Consequences in India: Levels, Patterns and Differentials. Department of Public Health and Mortality Studies. Mumbai: International Institute for Population Sciences. Available online at http://www.iipsindia.org/pdf/Childlessness\%20in\%20India.pdf

Rutstein. S.O., and I.H. Shah. 2004. Infecundity, Infertility, and Childlessness in Developing Countries. DHS Comparative Reports No 9. Calverton, MD: ORC Macro and the World Health Organization.

Shaw, R. 2013. Infertility and childlessness. Te Ara: The Encyclopedia of New Zealand. Retrieved May 25, 2013 from http:/ /www.TeAra.govt.nz/en/infertility-and-childlessness/print.

Singh, A.J., and L.K. Dhaliwal. 1993. Identification of infertile couples in a rural area of Northern India. Indian Journal of Medical Research 98:206-208.

Talwar, P.P., O.P. Go, and I.N. Murali. 1986. In Statistics and Demography: Prevalence of Infertility in Different Population Groups in India and Its Determinants. New Delhi: National Institute of Health and Family Welfare and Indian Council of Medic-al Research. 
Tripathi, N. 2011. Infertility among Indian Women: Emerging Evidence and Need for Policy Measures, Presented at the annual conference of the Population Association of America. Available online at http://paa2011.princeton.edu/papers/110609.

Unisa, S. 1999. Childlessness in Andhra Pradesh, India: Treatment seeking and consequences. Reproductive Health Matters 7:54-64.

- 2010. Infertility and treatment seeking in India: Findings from District Level Household Survey, in Social Aspects of Accessible Infertility Care in Developing Countries. Facts, Views and Vision in Obstetrics and Gynaecology: The Walking Egg Project. Wetteren (Belgium): Flemish Society of Human Reproduction and Embryology, p. 59-65.

United Nations. 1994. Principle 8. Program of Action. Cairo International Conference on Population and Development (ICPD). New York: United Nations.

WHO (World Health Organization). 1991. A Tabulation of Available Data on Prevalence of Primary and Secondary Infertility. WHO/MCH/91.9.

Widge, A., and J. Cleland. 2009. The public sector's role in infertility management in India. Health Policy and Planning 24:108-115.

Zargar, A.H., A.L. Wani, S.R. Masoodi, B.A. Laway, M. Salahuddin. 1997. Epidemiologic and etiologic aspects of primary infertility in the Kashmir region of India. Fertility and Sterility 68:637-43. 